\title{
ANALISA KEKASARAN HASIL PROSES KERJA MESIN SIMULATOR CNC ROUTER UNTUK MATERIAL ALUMUNIUM
}

\author{
PARTA \\ Program Studi Teknik Mesin, Fakultas Teknik, Universitas Muhammadiyah Tangerang \\ Jl. Perintis Kemerdekaan I/33 Cikokol-Tangerang \\ E-mail: partagumilang@yahoo.com
}

\begin{abstract}
Abstrak
Bentuk dan kekasaran permukaan dari sebuah produk yang dihasilkan oleh mesin perkakas seperti mesin bubut memegang peranan yang penting. Hal ini disebabkan oleh bentuk dan kekasaran permukaan produk tersebut berkaitan dengan gesekan, keausan, sistem pelumasan dan lain-lainnya. Proses permesinan akan menentukan kekasaran permukaan pada level tertentu dimana kekasaran permukaan tersebut dapat dijadikan acuan untuk evaluasi produk pemesinan. Kekasaran permukaan sebuah produk tidak harus memiliki nilai yang kecil.Dalam analisa kekasaran permukaan, tahapan yang dilakukan adalah pemilihan jenis material benda kerja dan jenis pahat potong yang sering digunakan pada bengkel-bengkel produksi di Indonesia. Material yang dipakai yaitu alumunium untuk proses selanjutnya adalah proses pembentukan ukiran sesuai dengan mesin CNC Router.Dari pengambilan data yang didapat bahwa Semakin tinggi kecepatan makan, maka tingkat / nilai kekasaran suatu permukaan benda yang didapat semakin tinggi begitu juga sebaliknya semakin rendah kecepatan makan, maka nilai kekasaran suatu permukaan benda yang didapat akan rendah.
\end{abstract}

Kata Kunci : Kekasaran Permukaan, CNC Router, Alumunium

\section{PENDAHULUAN}

Seni ukiran merupakan seni yang membentuk gambar pada permukaan kayu, batu, dan material lainnya. Kayu, batu dan material lainnya diukir dengan cara menoreh, menggores dan memahat dengan menggunakan pahat. Di Indonesia seni mengukir masih dilakukan dengan cara manual. Seni mengukir yang dilakukan dengan cara manual memerlukan waktu yang lama dan memerlukan biaya yang besar dalam proses pengerjaannya. Oleh karena itu untuk mengatasi kekurangan tersebut, mengukir dapat dilakukan dengan menggunakan mesin $\mathrm{CNC}$ router.

Mesin $\mathrm{CNC}$ router adalah mesin yang digunakan untuk membuat profil kayu, alumunium dan juga akrilik pada bidang permukaan datar. Alumunium yang diukir oleh mesin $\mathrm{CNC}$ router menghasilkan ukiran berkualitas baik dengan waktu pengerjaan yang singkat. Mesin $\mathrm{CNC}$ router dapat dipadukan dengan sebuah komputer yang memiliki pemograman numerik. Komputer yang memiiki pemograman numerik dapat mengontrol gerak alat potong mesin router. Mesin perkakas yang dikontrol oleh komputer dinamakan mesin perkakas CNC (Computer Numerically Controlled). Material yang dibuat mesin $\mathrm{CNC}$ menghasilkan produk berkualitas baik dan dibuat dengan waktu pengerjaan singkat. Pada mesin
CNC (Computer Numerically Controlled) terdapat beberapa code. Beberapa code yang terdapat pada mesin CNC (Computer Numerically Controlled) yaitu G-kode dan M-code. G-kode digunakan untuk menyatakan gerakan alat potong mesin perkakas, sedangkan M-kode digunakan untuk menyatakan fungsi mesin perkakas.

Sifat dan bentuk suatu permukaan material yang dihasilkan oleh CNC Router juga memegang peranan dalam perancangan komponen suatu material. Banyak hal dimana sifat permukaan perlu dilakukan pengujian kekasarannya dan dinyatakan dengan jelas misalnya dalam kaitannya dengan gesekan, keausan, tahanan, kelelehan dan sebagainya. Bentuk dan kekasaran permukaan dari sebuah produk yang dihasilkan oleh mesin perkakas seperti mesin bubut memegang peranan yang penting. Hal ini disebabkan oleh bentuk dan kekasaran permukaan produk tersebut berkaitan dengan gesekan, keausan, sistem pelumasan dan lain-lainnya. Setiap benda kerja hasil proses permesinan akan memiliki bentuk dan kekasaran permukaan tertentu seperti mengkilat, permukaan yang halus dan kasar. Proses permesinan akan menentukan kekasaran permukaan pada level tertentu dimana kekasaran permukaan tersebut dapat dijadikan acuan untuk evaluasi produk pemesinan. 
Kekasaran permukaan sebuah produk tidak harus memiliki nilai yang kecil, tetapi terkadang sebuah produk membutuhkan nilai kekasaran permukaan yang besar sesuai dengan fungsinya.

Untuk mendapatkan nilai kekasaran permukaan yang halus dari proses ukiran dapat dilakukan dengan pemilihan mata pahat, penentuan feeding dan kedalaman potong yang sesuai dengan kebutuhan. Ketajaman dan kekuatan dari mata pahat sangat berpengaruh terhadap produk yang dihasilkan. Dalam tugas akhir ini difokuskan pada penggunaan beberapa material pahat dan benda kerja untuk mengetahui pengaruh jenis pahat dan benda kerja terhadap kekasaran permukaan yang dihasilkan dan lamanya waktu pemotongan.

\section{METODOLOGI PENELITIAN 2.1. Persiapan Bahan Alumunium}

Bahan Alumunium dipilih dengan bidang balok dengan dimensi $9 \times 4 \times 3 \mathrm{~cm}$, dengan melakukan 5 kali percobaan. Untuk memudahkan penilaian terhadap tingakat kekasaran permukaan.

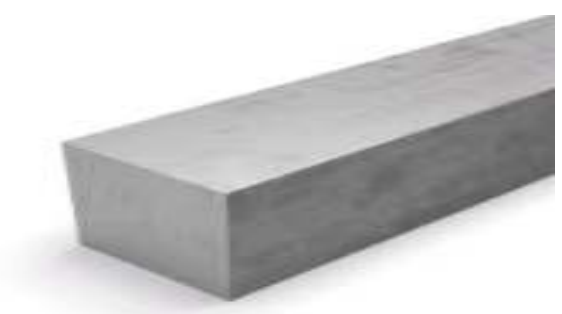

Gambar 2.1 Bahan Alumunium

\subsection{Observasi Material}

Dalam hal ini untuk mengetahui tingkat kekasaran maka dari bahan Alumunium di lakukan penyayatan dengan sistem variabel, diantaranya :

- Perubahan kecepatan

- Perubahan tekanan

- Ketajaman pahat

- Pelumasan

Dari perubahan - perubahan yang dilakukan menghasilkan tingkat kekasaran yang berbeda.

\subsection{Tingkat Kekasaran} alat

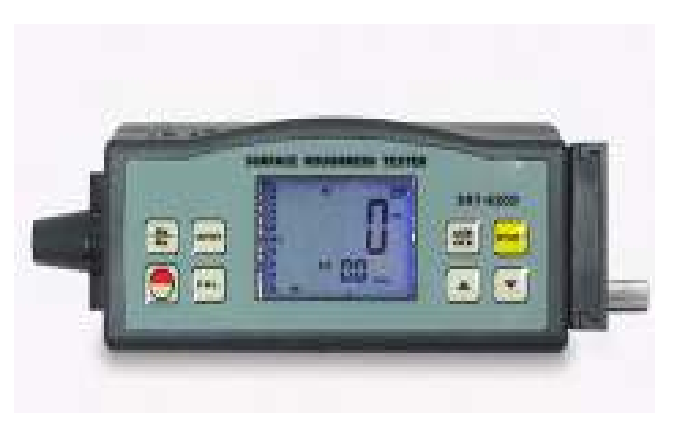

Gambar 2.2 Alat Uji Kekasaran Permukaan

\section{HASIL DAN PEMBAHASAN \\ 3.1 kekasaran Permukaan}

Kekasaran permukaan dari bagian-bagian mesin dan juga bekas pengerjaannya merupakan faktor yang sangat penting untuk menjamin mutu bagian-bagian, seperti misalnya suaian atau ketahanan, maupun tampak dari bagian-bagian. Penunjukan konfigurasi permukaan yang mencakup kekasaran permukaan, arah bekas pengerjaan dan sebagainya, diperlukan untuk menjamin tujuan-tujuan diatas.Perincian konfigurasi permukaan tidak diperlukan jika proses pembuatan biasa dapat menjamin pengerjaan akhir yang dapat diterima.Dalam proses pemesinan (machining process), kekasaran permukaan (surface roughness) merupakan sifat yang penting, karena sifat ini menentukan kualitas produk yang dihasilkan. Maka dengan demikian kita dapat menentukan tingkat kekasaran yang diinginkan atau sesuai dengan aplikasi produk tersebut

\subsection{Tingkat Kekasaran Material}

Tingkat kekasaran kita dapat menggunakan variabel kecepatan, ketajaman pahat dan tekanan / kedalaman penyayatan, tentunya dengan mengimbangi antara kecepatan dan penyayatan benda kerja. 


$$
V_{c}=\frac{\pi \times d \times n}{1000}
$$

\section{Diagram Alur Penelitian}

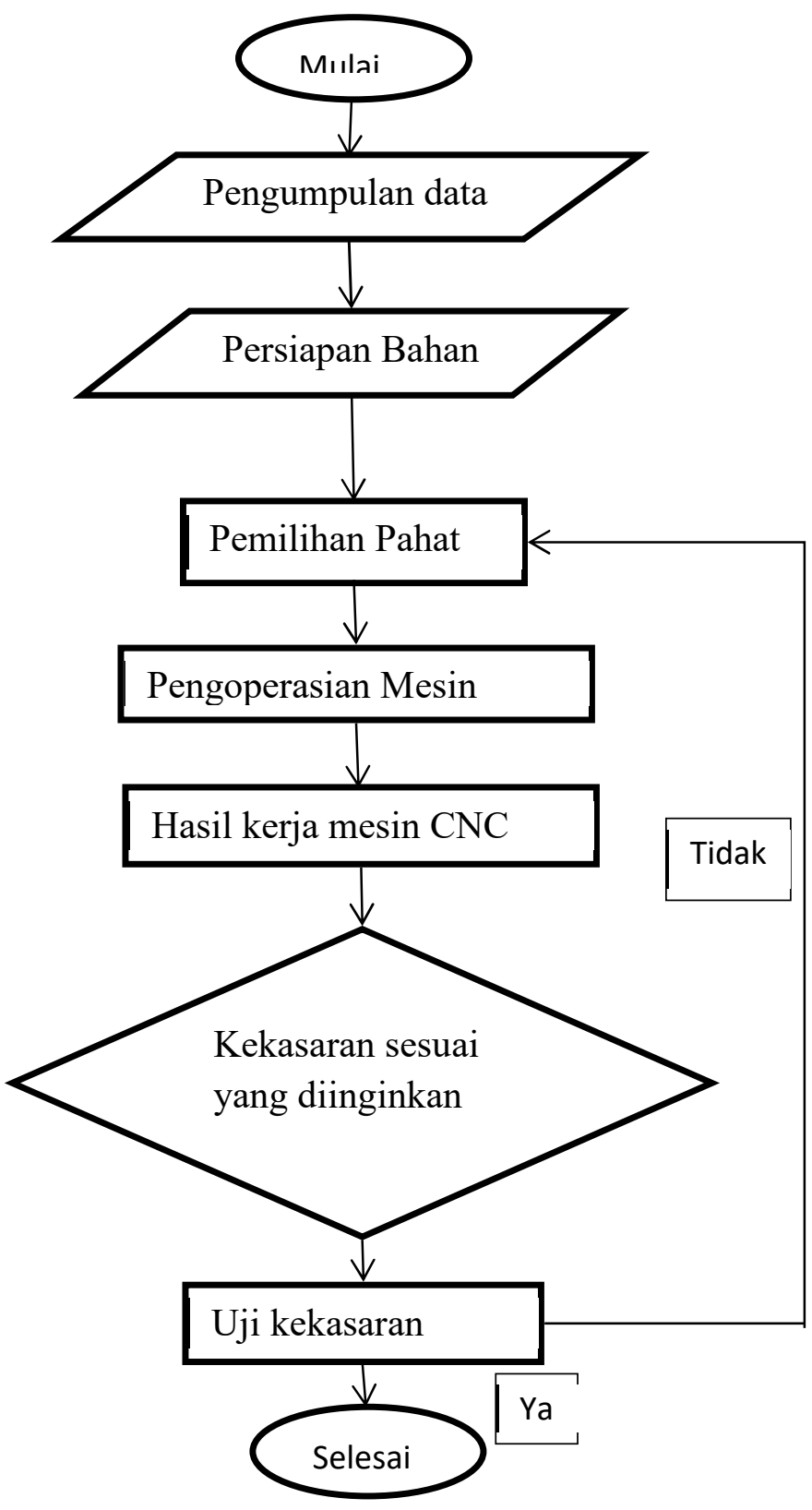

2. Hubungan Antara Putaran Spindle dan Kecepatan Makan Terhadap Kekasaran Permukaan.

a. Kecepatan Potong untuk menghitung kecepatan potong dari suatu proses pembentukan benda kerja pada mesin dengan mengunakan persamaan.
Dimana :

$$
\begin{aligned}
& V_{C}=\text { kecepatan potong }(\mathrm{mm} / \text { menit }) \\
& d=\text { diameter pahat }(\mathrm{mm}) \\
& n=\text { kecepatan putar }(\mathrm{rpm}) \\
& \pi=3,14
\end{aligned}
$$

Dengan putaran spindle 300 rpm maka:

$$
\begin{aligned}
V_{C} & =\frac{3.14 \times 3 \mathrm{~mm} \times 300}{1000} \\
V_{C} & =2.826 \mathrm{~mm} / \mathrm{menit}
\end{aligned}
$$

Dengan putaran spindle 700 rpm maka:

$$
\begin{aligned}
V_{C} & =\frac{3.14 \times 3 \mathrm{~mm} \times 700}{1000} \\
V_{C} & =6.59 \mathrm{~mm} / \mathrm{menit}
\end{aligned}
$$

Dengan putaran spindle 1300 rpm maka:

$$
\begin{aligned}
V_{C} & =\frac{3.14 \times 3 \mathrm{~mm} \times 1300}{1000} \\
V_{C} & =12.246 \mathrm{~mm} / \mathrm{menit}
\end{aligned}
$$

Jadi dengan ini dapat kita simpulkan bahwa semakin besar putaran sepindle maka semakin banyak pemakanan yang dilakukan begitu juga sebaliknya, semakin kecil putaran sepindle maka semakin kecil pemakanan yang dilakukan.

\section{b. Kecepatan makan}

Kemudian untuk menghitung kecepatan makan dari suatu proses pembentukan benda kerja pada mesin mengunakan persamaan :

$$
V=f \times n
$$

Dimana :

$$
\begin{aligned}
& V=\operatorname{kecepatan} \operatorname{makan}(\mathrm{mm} / \text { menit}) \\
& f=\operatorname{gerak} \operatorname{makan}(\mathrm{mm} / \mathrm{r}) \\
& n=\operatorname{kecepatan} \operatorname{putar}(\mathrm{rpm})
\end{aligned}
$$




$$
\begin{aligned}
& V=0.015 \times 300 \\
& V=4.5 \mathrm{~mm} / \text { menit }
\end{aligned}
$$

c. Waktu pemotongan

Kemudian untuk menghitung waktu pemotongan dari suatu proses pembentukan benda kerja pada mesin menggunakan persamaan :

$$
t_{C}=\frac{l_{t}}{V_{f}}
$$

Dimana :

$$
\begin{gathered}
l_{t}=\text { panjang pemotongan }(\mathrm{mm}) \\
t_{C}=\text { waktu pemotongan (menit) } \\
V_{f}=\text { kecepatan makan (mm/menit) } \\
t_{C}=\frac{70 \mathrm{~mm}}{4,5 \mathrm{menit}} \\
t_{C}=15.55 \mathrm{~mm} / \text { menit }
\end{gathered}
$$

\section{d. Kecepatan Penghasil Geram}

Kemudian untuk menghitung kecepatan penghasilan geram dari suatu proses pembentukan benda kerja pada mesin bubut menggunakan persamaan :

$$
Z=\frac{f \times V_{C} \times v}{1000}
$$

Dimana : $Z=$ kecepatan penghasilan geram (cm3/menit)

$$
\begin{aligned}
& Z=\frac{0.015 \times 2.826 \times 45}{1000} \\
& Z=0.01907 \mathrm{~cm} 3 / \text { menit }
\end{aligned}
$$

\section{Pengaruh Putaran Spindle Terhadap Nilai Kekasaran yang dihasilkan.}

\section{a. Perhitungan statistik}

Benda uji yang telah dilakukan proses dengan variasi putaran sepindle (n) dan kecepatan makan $\left(V_{f}\right)$ - selanjutnya dilakukan uji kekasaran ( surface roughness tester) dan didapat data-data yang selanjutnya diolah dengan metode statistik korelasi.

\begin{tabular}{|c|c|c|c|c|c|}
\hline \multirow{2}{*}{ No } & \multicolumn{2}{|c|}{$\begin{array}{c}\text { Putaran } \\
\text { Spindle(n) }\end{array}$} & \multicolumn{3}{c|}{$\begin{array}{c}\text { Kekasaran Permukaan } \\
(\mathrm{Ra})\end{array}$} \\
\cline { 2 - 6 } & $\mathrm{X}$ & $\mathrm{X}^{2}$ & $\mathrm{Y}$ & $\mathrm{Y}^{2}$ & $\mathrm{XY}$ \\
\hline 1 & 300 & 90000 & 4.53 & 20.521 & 1359 \\
\hline 2 & 300 & 90000 & 6.10 & 37.210 & 1830 \\
\hline 3 & 300 & 90000 & 8.34 & 69.556 & 2502 \\
\hline 4 & 700 & 490000 & 3.72 & 13.838 & 2604 \\
\hline 5 & 700 & 490000 & 4.83 & 23.329 & 3381 \\
\hline 6 & 700 & 490000 & 6.28 & 38.813 & 4361 \\
\hline 7 & 1300 & 1690000 & 2.48 & 6.150 & 3224 \\
\hline 8 & 1300 & 1690000 & 3.44 & 11.834 & 4472 \\
\hline 9 & 1300 & 1690000 & 3.34 & 18.836 & 5642 \\
\hline$\sum$ & 6900 & 6810000 & 44.01 & 240.086 & 29375 \\
\hline
\end{tabular}

Tabel Variasi putaran Spindle terhadap Kekasaran permukaan

Metode statistik adalah jika variabel $\mathrm{X}$ dan $\mathrm{Y}$ dianggap berasosiasi atau bekolerasi secara statistic jika hubungannya terdapat antar kedua batas bawah.

$$
r=\frac{n \cdot \sum X Y-\sum X \cdot \sum Y}{\sqrt{n \cdot \sum X^{2}-\left(\sum X\right)^{2} \sqrt{n \cdot \sum Y^{2}-\left(\sum Y\right)^{2}}}}
$$

Pada hakekatnya, nilai $r$ dapat bervariasi dari -1 melalui 0 hingga +1 . Statistik hipotesis $t$ dapat digunakan untuk menguji apakah $r$ benar-benar beda dari nol secara berarti. Uji hipotesis dengan nilai $\mathrm{t}$ dapat dicari dengan:

$$
t=\frac{r \sqrt{n-2}}{\sqrt{1-r^{2}}}
$$

Akan memiliki distribusi $t$ dengan derajat bebas sebesar n- 2 .

Variasi putaran Spindle (n) terhadap Kekasaran permukaan (Ra).

Dimana :

$$
\begin{aligned}
& \mathrm{n}=9 \\
& \mathrm{df}=\mathrm{n}-2=9-2=7 \text { (Derajat Kebebasan) } \\
& \text { taraf Signifikan }=5 \% \\
& \sum X=6900 \\
& \sum \mathrm{X}^{2}=6810000 \\
& \sum \mathrm{Y}=44.01 \\
& \sum \mathrm{Y}^{2}=240.086 \\
& \sum X Y=29375
\end{aligned}
$$

Maka koefisien (r) dapat dicari dengan rumus : 


$$
\begin{gathered}
r=\frac{n \cdot \sum X Y-\sum X \cdot \sum Y}{\sqrt{n \cdot \sum X^{2}-\left(\sum X\right)^{2} \sqrt{n \cdot \sum Y^{2}-\left(\sum Y\right)^{2}}}} \\
=\frac{9 .(29375)-(6900) \cdot(44.01)}{\sqrt{9 .(6810000)-(6900)^{2} \sqrt{9 \cdot(240.086)-(44.01)^{2}}}} \\
r=\frac{264375-303669}{(3698.65) \cdot(14.96)} \\
r=\frac{-39294}{55343.52} \\
r=-0.710
\end{gathered}
$$

Berdasarkan nilai statistik nilai $\mathrm{r}$ adalah $\mathrm{r}<1$ dan $\mathrm{r}<-1$, maka nilai $\mathrm{r}$ hitung $=-0.710$, jadi $-0.710<$ -1, sehingga dapat dikatakan bahwa putaran spindle dengan nilai kekasaran permukaan suatu benda terdapat hubungan linier negatif yang kuat. Selanjutnya dilakukan uji hipotesis nilai $t$, dapat dicari dengan :

$$
\begin{gathered}
t=\frac{r \sqrt{9-2}}{\sqrt{1-r^{2}}} \\
t=\frac{0.710 \sqrt{n-2}}{\sqrt{1-(-0.710)^{2}}} \\
t=\frac{(0.710) \cdot(2.62)}{\sqrt{1-0.504}} \\
t=\frac{-1.874}{0.704} \\
t=-2.662
\end{gathered}
$$

Jadi t hitung $=-2.662,>-1$ dengan demikian hipotesa hubungan antara putaran spindle dengan tingkat nilai kekasaran permukaan benda terdapat pengaruh yang signifikan.

\section{Grafik pengaruh pemakanan benda kerja dan geometri sudut potong pahat terhadap nilai kekasaran.}

Hal yang sangat penting diperhatikan adalah bagaimana alat potong dapat menyayat dengan baik, dan untuk dapat menyayat dengan baik alat potong diperlukan adanya sudut baji, sudut bebas dan sudut tatal sesuai ketentuan, yang semua Ini disebut dengan istilah geometris alat potong.

Berikut merupakan grafik pengaruh sudut potong terhadap kekasaran permukaan yang didapat setelah melakukan pengujian dengan tingkat sudut yang berbeda.

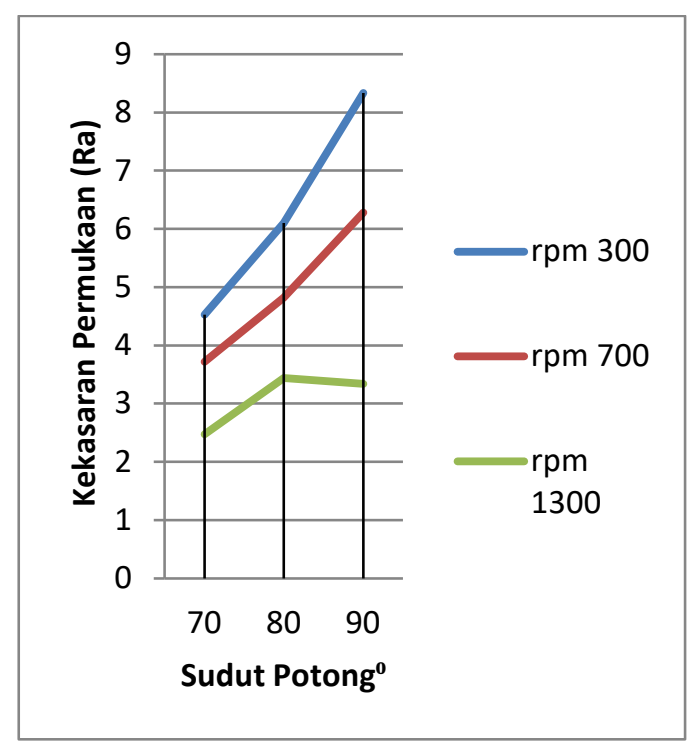

Grafik Pengaruh Sudut Potong Terhadap Kekasaran

Dari grafik diatas maka dapat dilihat dengan kecepatan spindel $300 \mathrm{rpm}$ dan sudut potong $70^{\circ}$ didapat nilai kekasaran $4.53 \mu \mathrm{m}$ lalu dengan kecepatan spindel $300 \mathrm{rpm}$ dan sudut potong $80^{\circ}$ didapat nilai kekasaran $6.10 \mu \mathrm{m}$ lalu dengan kecepatan spindel 300 rpm dan sudut potong $90^{\circ}$ didapat nilai kekasaran 8.34 $\mu \mathrm{m}$ lalu dengan kecepatan spindel $700 \mathrm{rpm}$ dan sudut potong $70^{\circ}$ didapat nilai kekasaran $3.72 \mu \mathrm{m}$ lalu dengan kecepatan spindel $700 \mathrm{rpm}$ dan sudut potong $80^{\circ}$ didapat nilai kekasaran $4.83 \mu \mathrm{m}$ lalu dengan kecepatan spindel $700 \mathrm{rpm}$ dan sudut potong $90^{\circ}$ didapat nilai kekasaran $6.28 \mu \mathrm{m}$ lalu dengan kecepatan spindel $1300 \mathrm{rpm}$ dan sudut potong $70^{\circ}$ didapat nilai kekasaran $2.48 \mu \mathrm{m}$ lalu dengan kecepatan spindel $1300 \mathrm{rpm}$ dan sudut potong $80^{\circ}$ didapat nilai kekasaran $3.44 \mu \mathrm{m}$ lalu dengan kecepatan spindel $1300 \mathrm{rpm}$ dan sudut potong $90^{\circ}$ didapat nilai kekasaran $3.34 \mu \mathrm{m}$. Dari pernyataan diatas dapat disimpulkan bahwa sudut potong pada proses bubut memiliki pengaruh terhadap kekasaran permukaan benda kerja. Yang artinya semakin besar sudut potong makan akan semakin tinggi nilai tingkat kekasaran permukaan yang akan terjadi.

\section{KESIMPULAN}


1. Nilai kekasaran permukaan lebih dipengaruhi oleh parameter kecepatan spindle. Semakin tinggi kecepatan spindle maka nilai kekasaran permukaan yang didapat semakin rendah begitu juga sebaliknya semakin rendah putaran sepindle maka nilai kekasaran permukaan yang didapat semakin tinggi.

2. Semakin tinggi kecepatan makan, maka tingkat / nilai kekasaran suatu permukaan benda yang didapat semakin tinggi begitu juga sebaliknya semakin rendah kecepatan makan, maka nilai kekasaran suatu permukaan benda yang didapat akan rendah.

3. Hubungan antara sudut potong pada proses bubut memiliki pengaruh terhadap kekasaran permukaan benda kerja. Yang artinya semakin besar sudut potong makan akan semakin tinggi nilai tingkat kekasaran permukaan yang akan terjadi.

\section{DAFTAR PUSTAKA}

Bodig, J. and Jayne, B.A. (1982) 'Mechanics of Wood and Wood Composites' Van Nostrand Reinholt Company, New York, U.S.A.

Emco, 1990. Petunjuk Pemrograman - Pelayanan Emco TU - 2A.Emco Maier Ges.m.b.H, Austria.

G. Niemann. 1999. Elemen Mesin jilid 1. Jakarta: Erlangga. Gadjahmada University Press. Yogyakarta.

Kuspriyanto dan Seputro, Hari. Mesin CNC. Fakultas Teknologi Industri, Intitut Teknologi Bandung.

Rochim, Taufik. 1993. Teori dan Teknologi Proses. ITB Bandung.

R.S. Khurmi and J.K. Gupta. (2005). A Textbook of Machine Design. Eurasia Publishing House (PVT.) LTD., New Delhi, India.

Sularso dan Kiyokatsu Suga (1997) Dasar Perencanaan dan Pemilihan Elemen Mesin. Jakarta : PT. Pradnya Paramitha.

Syahrul, 2011, Motor Stepper: Teknologi, Metoda Dan Rangkaian Kontrol, Majalah Ilmiah UNIKOM, No.2, Vol. 6, Halaman 187202,http://jurnal.unikom. ac.id/.

Takeshi Sato dan N. Sugiarto Harianto (1999). Menggambar Mesin Menurut Standar ISO. Jakarta : PT. Pradnya Paramita.

Widarto. 2008. Teknik Pemesinan Jilid 1. Direktorat Pembinaan Sekolah Menengah Kejuruan. Departemen Pendidikan Nasional. Jakarta. 